\title{
Stump Diameter and Diameter at Breast Height Relationships for Oriental Beech and Kazdağı Fir at Mixed Stands in Karabük
}

\author{
Oytun Emre SAKICI ${ }^{1 *}$, Gulay OZDEMIR ${ }^{2}$ \\ ${ }^{1}$ Kastamonu University, Faculty of Forestry, Department of Forest Engineering, Kastamonu, Turkey \\ ${ }^{2}$ Kastamonu University, Institute of Science, Forest Engineering Program, Kastamonu, Turkey \\ *Corresponding Author: oesakici@kastamonu.edu.tr
}

Received Date: 17.03.2017

Accepted Date: 03.08.2017

\section{Abstract}

Aim of study: The aim of this study was to evaluate the relationships between stump diameters ( $d_{0.10}$ and $\left.d_{0.30}\right)$ at two different stump heights $(10 \mathrm{~cm}$ and $30 \mathrm{~cm}$ above ground level) and diameter at breast height $\left(d_{1.30}\right)$ for mixed stands of Oriental beech (Fagus orientalis) and Kazdağ 1 fir (Abies nordmanniana subsp. equi-trojani) located in Karabük region.

Area of study: Study area is located on Büyükdüz Forest Planning Unit of Karabük Forest Enterprise of Zonguldak Regional Directorate of Forestry at Western Blacksea region of Turkey.

Material and Methods: A total of 516 sample trees (238 for Oriental beech and 278 for Kazdağ fir) were measured for $d_{0.10}, d_{0.30}$ and $d_{1.30}$. To model the relationships between stump diameters and diameter at breast height, ten candidate equations were tested. These equations were ranked according to Coefficient of Determination $\left(R^{2}\right)$, Root Mean Square Error $(R M S E)$ and Mean Absolute Error (MAE), and successful models were selected based on average rank values.

Main results: Among equations tested, the power equation had the lowest average rank values for determining $d_{0.10}-d_{1.30}$ and $d_{0.30}-d_{1.30}$ relationships of both species and provided the best $d_{1.30}$ predictions. $R^{2}$, $R M S E$ and MAE values of the power equation are $0.981,3.64$ and 2.58 for $d_{0.10-} d_{1.30}$ relationship and 0.989 , 2.01 and 1.36 for $d_{0.30}-d_{1.30}$ relationship for Oriental beech, and $0.955,3.80$ and 2.81 for $d_{0.10^{-}} d_{1.30}$ relationship and $0.988,1.96$ and 1.28 for $d_{0.30}-d_{1.30}$ relationship for Kazdağ fir, respectively.

Research highlights: The equations developed can be used to estimate diameters at breast height of trees extracted from the stand for any reason, and volume of these trees can be predicted in a practical way by using single entry volume equations with the estimated diameters at breast heights.

Keywords: Diameter at breast height, Stump diameter, Mixed stand, Oriental beech, Kazdağı fir.

\section{Karabük Yöresi Doğu Kayını-Kazdağı Göknarı Karışık Meşcerelerinde Dip Kütük Çapı-Gögüis Çapı İlişkileri}

Özet

Çalışmanın amacı: Bu çalışmanın amacı, Karabük yöresi karışık meşcerelerinde bulunan Doğu kayını (Fagus orientalis) ve Kazdağı göknarı (Abies nordmanniana subsp. equi-trojani) türleri için iki farklı yükseklikten (10 $\mathrm{cm}$ ve $30 \mathrm{~cm})$ ölçülen dip kütük çapları $\left(d_{0.10}\right.$ ve $\left.d_{0.30}\right)$ ile göğüs çapları $\left(d_{1.30}\right)$ arasındaki ilişkilerin araştırılmasıdır.

Çalışma alanı: Araştırma, Zonguldak Orman Bölge Müdürlüğü’ne bağlı Karabük Orman İşletme Müdürlüğü’nün Büyükdüz Orman İşletme Şefliği'nde yürütülmüştür.

Materyal ve Yöntem: Araştırma materyali olarak toplam 516 örnek ağaçta (238 adet Doğu kayını ve 278 adet Kazdağ1 göknarı) yapılan dip kütük çapı ve göğüs çapı ölçümlerinden yararlanılmıştır. Dip kütük çapları ile göğüs çapı arasındaki ilişkilerin modellenmesinde on regresyon denklemi test edilmiştir. Denklemler Belirtme Katsayısı $\left(R^{2}\right)$, Hataların Ortalama Karekökü $(R M S E)$ ve Ortalama Mutlak Hata $(M A E)$ ölçütlerine göre sıralanmış ve en başarılı modeller belirlenmiştir.

Sonuçlar: $d_{0.10^{-}} d_{1.30}$ ve $d_{0.30}-d_{1.30}$ ilişkileri için incelenen denklemler arasında her iki ağaç türü için de power denklemi en başarılı denklem olmuştur. Bu denkleme göre elde edilen $d_{0.10}-d_{1.30}$ ve $d_{0.30}-d_{1.30}$ ilişkilerine ilişkin $R^{2}, R M S E$ ve $M A E$ değerleri; Doğu kayını için sırasıyla $0.981,3.64$ ve 2.58 ile $0.989,2.01$ ve 1.36 iken, Kazdağı göknarı için sırasıyla $0.955,3.80$ ve 2.81 ile $0.988,1.96$ ve 1.28 'dir.

Araştırma vurgulart: Çalışma kapsamında geliştirilen denklemler, meşcereden uzaklaştırılan ağaçların göğüs çapı tahmininde kullanılabilecek ve hacim hesaplamalarında bu tahminlerden yararlanılabilecektir.

Anahtar kelimeler: Göğüs çapı, Dip kütük çapı, Karışık meşcere, Doğu kayını, Kazdağı göknarı. 


\section{Introduction}

Forest inventory is the main way of obtaining information needed to ensure the sustainability of the forest resource utilization (Köhl, 2004). Forest inventory constitutes the basis of all planning processes in forestry (Firat, 1973). One of the most important issues of forest inventory is stand volume. Although there are a number of methods to estimate stand volume in the forestry literature, tree volume tables are generally preferred due to their practicality. Depending on the number of independent variables used, tree volume tables are usually classified into three types as single, double and multipleentry tree volume tables. Single-entry tree volume tables depend on only diameter at breast height of trees, double-entry tree volume tables depend on tree height and diameter at breast height, while multiple-entry tree volume tables as a function of some other tree size as well as additional diameter at breast height and tree height (Kalıpsız, 1999).

Single-entry volume tables are more preferred, because diameter at breast height is an easily and accurately measured parameter (Vanclay, 1994; Kalıpsiz, 1999). However, many features (e.g. diameter at breast height and tree height) of trees removed from the field as a result of planned or illegal cuttings cannot be revealed and hence the tree volume cannot be estimated with these tables. Since trees are usually cut at the stump height, determining the relationships between stump diameter and diameter at breast height in order to compute the volume using the diameters at breast height of the trees is of very great importance (Yavuz, 2000). Stump diameter shows a high correlation with diameter at breast height, so the equations using stump diameter as independent variable are useful tools to estimate diameter at breast height of removed trees. Then, estimated diameters at breast height with these equations can be used for volume predictions. There are many researches on relationships between stump diameter and diameter at breast height for various tree species (e.g. Alemdag and Honer, 1977; Bylin, 1982; Demaerschalk and Omule, 1982; Omule and Kozak, 1989; Kozak and Omule, 1992; Weigel and Johnson, 1997; Corral-Rivas et al., 2007; Uğurlu and Özer, 1977; Özer, 1981; Giray, 1982; Yavuz, 1996;
Yavuz, 2000; Özçelik, 2005; Durkaya and Durkaya, 2011; Şenyurt, 2012; Ercanlı et.al., 2015; Sağlam et al., 2016). The studies on this subject, conducted in Turkey, were only interested in stump diameter at $30 \mathrm{~cm}$ height except one of Durkaya and Durkaya (2011) who explained the relationships between stump diameter and diameter at breast height for different stump heights range from $10 \mathrm{~cm}$ to $60 \mathrm{~cm}$. Considering that trees are cut as close to the ground as possible recently, the relationships between some other stump diameters at other heights than $30 \mathrm{~cm}$ and diameter at breast height are also important.

Oriental beech (Fagus orientalis Lipsky.) and Kazdağ fir (Abies nordmanniana subsp. equi-trojani (Asc. \& Sint. ex Boiss.) Coode \& Cullen) are both of main forest tree species in Turkey. They are very important in terms of economically and ecologically. Kazdağ fir is an endemic species of Turkey and spreads northwestern and western parts of country, and the main distribution area of Oriental beech in Turkey is Blacksea region. In these regions, these species form large pure stands as well as mixed stands together (Anşin and Özkan, 1993).

The aim of this study was to evaluate the relationships between stump diameters at two different stump heights and diameter at breast height for mixed stands of Oriental beech and Kazdağ1 fir located in Karabük region. For this purpose, stump diameters and diameters at breast height of sample trees were measured. Depending on the data obtained, the various regression equations were tested and the equations that giving the best results were determined for both tree species. These equations can be used to estimate diameter at breast heights required for volume predictions.

\section{Material and Method}

Study area is located in Karabük Forest Enterprise of Zonguldak Regional Directorate of Forestry at Western Blacksea region of Turkey. The total area of Karabük Forest Enterprise is $113,746.20$ ha, and $75 \%$ of total area $(85,111.60 \mathrm{ha})$ is covered by forests (URL, 2017). Main tree species of these forests are Pinus nigra, Fagus orientalis, Abies nordmanniana subsp. equi-trojani and Quercus sp. 
To model the relationships between stump diameters $\left(d_{0.10}, d_{0.30}\right)$ at two different stump heights $(10 \mathrm{~cm}$ and $30 \mathrm{~cm}$ above ground level) and diameter at breast height $\left(d_{1.30}\right)$, the data obtained from measurements in Oriental beech-Kazdaği fir mixed stands located on Büyükdüz Planning Unit of Karabük Forest Enterprise were used. For this purpose, a total of 516 sample trees (238 for Oriental beech and 278 for Kazdağ fir) were measured for $d_{0.10}, d_{0.30}$ and $d_{1.30}$. Separately for both species, $75 \%$ of the data (178 and 208 sample trees for beech and fir, respectively) were randomly selected and used for model development, and remaining 25\% (60 and 70 sample trees for beech and fir, respectively) were used for testing the validation of the tested models. Descriptive statistics of the model development and validation data are given in Table 1 . The table shows that the mean $d_{0.10}, d_{0.30}$ and $d_{1.30}$ values of beech sample trees are $52.1 \mathrm{~cm}, 46.6 \mathrm{~cm}$ and $43.9 \mathrm{~cm}$ for model development data and $51.6 \mathrm{~cm}, 46.7$ $\mathrm{cm}$ and $44.4 \mathrm{~cm}$ for validation data, respectively. For fir sample trees, the mean values are $54.4 \mathrm{~cm}, 47.4 \mathrm{~cm}$ and $44.4 \mathrm{~cm}$ for model development data and $53.7 \mathrm{~cm}, 46.6 \mathrm{~cm}$ and $43.5 \mathrm{~cm}$ for validation data, respectively. $d_{0.10^{-}} d_{1.30}$ and $d_{0.30^{-}} d_{1.30}$ relationships obtained from sample trees are given in Figure 1. For the purpose of modeling these relationships, equations given Table 2 were tested.

Table 1. Descriptive statistics for the model development and validation data

\begin{tabular}{|c|c|c|c|c|c|c|c|}
\hline Species & Data Group & Variable & $n$ & $\begin{array}{l}\text { Min. } \\
(\mathrm{cm})\end{array}$ & $\begin{array}{l}\text { Max. } \\
(\mathrm{cm})\end{array}$ & $\begin{array}{r}\text { Mean } \\
(\mathrm{cm})\end{array}$ & $\begin{array}{l}\text { Std Dev. } \\
(\mathrm{cm})\end{array}$ \\
\hline \multirow[t]{9}{*}{ Fagus orientalis } & Model & Stump diameter at $10 \mathrm{~cm}\left(d_{0.10}\right)$ & 178 & 15.8 & 98.2 & 52.1 & 18.3 \\
\hline & \multirow[t]{2}{*}{ Development } & Stump diameter at $30 \mathrm{~cm}\left(d_{0.30}\right)$ & 178 & 12.9 & 91.4 & 46.6 & 16.9 \\
\hline & & Diameter at breast height $\left(d_{1.30}\right)$ & 178 & 10.1 & 88.5 & 43.9 & 16.4 \\
\hline & \multirow[t]{3}{*}{ Validation } & Stump diameter at $10 \mathrm{~cm}\left(d_{0.10}\right)$ & 60 & 17.7 & 88.8 & 51.6 & 17.5 \\
\hline & & Stump diameter at $30 \mathrm{~cm}\left(d_{0.30}\right)$ & 60 & 15.1 & 82.1 & 46.7 & 16.4 \\
\hline & & Diameter at breast height $\left(d_{1.30}\right)$ & 60 & 14.0 & 80.1 & 44.4 & 15.9 \\
\hline & \multirow[t]{3}{*}{ All } & Stump diameter at $10 \mathrm{~cm}\left(d_{0.10}\right)$ & 238 & 15.8 & 98.2 & 52.0 & 18.1 \\
\hline & & Stump diameter at $30 \mathrm{~cm}\left(d_{0.30}\right)$ & 238 & 12.9 & 91.4 & 46.7 & 16.8 \\
\hline & & Diameter at breast height $\left(d_{1.30}\right)$ & 238 & 10.1 & 88.5 & 44.0 & 16.2 \\
\hline \multirow{9}{*}{$\begin{array}{l}\text { Abies nordmanniana } \\
\text { subsp. equi-trojani }\end{array}$} & Model & Stump diameter at $10 \mathrm{~cm}\left(d_{0.10}\right)$ & 208 & 16.0 & 115.5 & 54.4 & 19.4 \\
\hline & \multirow{2}{*}{ Development } & Stump diameter at $30 \mathrm{~cm}\left(d_{0.30}\right)$ & 208 & 13.0 & 104.0 & 47.4 & 17.9 \\
\hline & & Diameter at breast height $\left(d_{1.30}\right)$ & 208 & 11.4 & 100.1 & 44.4 & 17.4 \\
\hline & \multirow[t]{3}{*}{ Validation } & Stump diameter at $10 \mathrm{~cm}\left(d_{0.10}\right)$ & 70 & 18.0 & 95.7 & 53.7 & 19.1 \\
\hline & & Stump diameter at $30 \mathrm{~cm}\left(d_{0.30}\right)$ & 70 & 13.9 & 89.0 & 46.6 & 18.0 \\
\hline & & Diameter at breast height $\left(d_{1.30}\right)$ & 70 & 10.8 & 84.7 & 43.5 & 17.3 \\
\hline & \multirow[t]{3}{*}{ All } & Stump diameter at $10 \mathrm{~cm}\left(d_{0.10}\right)$ & 278 & 16.0 & 115.5 & 54.2 & 19.3 \\
\hline & & Stump diameter at $30 \mathrm{~cm}\left(d_{0.30}\right)$ & 278 & 13.0 & 104.0 & 47.2 & 17.9 \\
\hline & & Diameter at breast height $\left(d_{1.30}\right)$ & 278 & 10.8 & 100.1 & 44.2 & 17.3 \\
\hline
\end{tabular}

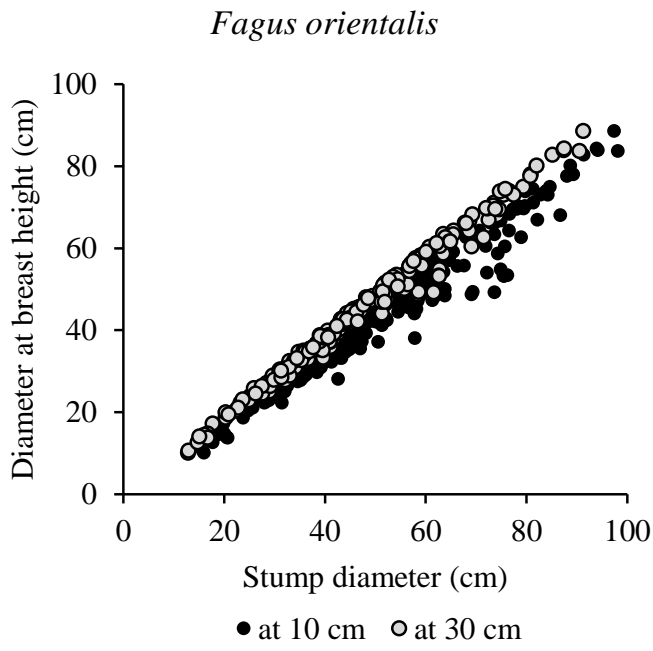

Abies nordmanniana subsp. equi-trojani

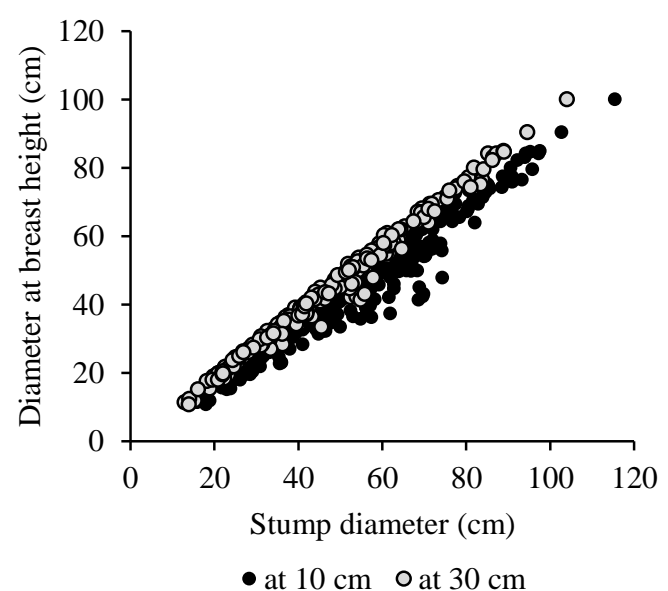

Figure 1. Stump diameters and diameter at breast height relationships 
Table 2. Equations used for modeling the relationships ${ }^{*}$

\begin{tabular}{llc}
\hline Model name & Model form & No. \\
\hline Linear & $d_{1.30}=b_{0}+b_{1} d_{i}$ & $(1)$ \\
Logarithmic & $d_{1.30}=b_{0}+b_{1} \ln d_{i}$ & $(2)$ \\
Inverse & $d_{1.30}=b_{0}+b_{1} / d_{i}$ & $(3)$ \\
Quadratic & $d_{1.30}=b_{0}+b_{1} d_{i}+b_{2} d_{i}^{2}$ & $(4)$ \\
Cubic & $d_{1.30}=b_{0}+b_{1} d_{i}+b_{2} d_{i}^{2}+b_{3} d_{i}^{3}$ & $(5)$ \\
Compound & $d_{1.30}=b_{0} b_{1}^{d_{i}}$ & $(6)$ \\
Power & $d_{1.30}=b_{0} d_{i}^{b_{1}}$ & $(7)$ \\
S & $d_{1.30}=e^{b_{0}+b_{1} / d_{i}}$ & $(8)$ \\
Growth & $d_{1.30}=e^{b_{0}+b_{1} d_{i}}$ & $(9)$ \\
Exponential & $d_{1.30}=b_{0} e^{b_{1} d_{i}}$ & $(10)$ \\
\hline${ }^{*} d_{1.30}$ : Diameter at breast height $(\mathrm{cm}), d_{i}$ : Stump diameter $\left(d_{0.10}\right.$ or $d_{0.30}$ according to stump heights, $\left.\mathrm{cm}\right), b_{i}$ : Equation parameters.
\end{tabular}

For the selection of successful models among the tested equations, Coefficient of Determination $\left(R^{2}\right)$, Root Mean Square Error $(R M S E)$ and Mean Absolute Error (MAE) were utilized. Corresponding mathematical forms of statistical criteria used were defined as:

$$
\begin{aligned}
& R^{2}=1-\frac{\sum\left(y_{i}-\hat{y}_{i}\right)^{2}}{\sum\left(y_{i}-\bar{y}\right)^{2}} \\
& R M S E=\sqrt{\frac{\sum\left(y_{i}-\hat{y}_{i}\right)^{2}}{n-p}} \\
& M A E=\frac{\sum\left|\hat{y}_{i}-y_{i}\right|}{n}
\end{aligned}
$$

In these equations; $y_{i}$ : observed value, $\hat{y}_{i}$ : estimated value, $p$ : number of parameters, and $n$ : sample size.

The models were ranked from 1 to 10 based on each criterion. The model with the highest $R^{2}$ was ranked as 1 and the lowest $R^{2}$ was ranked as 10 for coefficient of determination, while the model with the lowest value was ranked as 1 and the highest value was ranked as 10 for RMSE and MAE. The average of these three ranks for a given model was then calculated. Comparing the average ranks of the models, the best models were determined for both stump diameters, separately.

Validity of equations developed were tested using Paired Samples t-Test. IBM SPSS Statistics 23 software was used for statistical analyzes conducted during the study.

\section{Results and Discussion}

Values of the parameter estimates $\left(b_{i}\right)$, Coefficient of Determination $\left(R^{2}\right)$, Root Mean Square Error (RMSE) and Mean Absolute Error $(M A E)$ for the developed models to determine the relationships between stump diameters and diameter at breast height for Oriental beech and Kazdağ 1 fir in mixed stands located Büyükdüz Forest Planning Unit are given in Table 3. As seen in the table, the large majority of the equations explained more than $90 \%$ of the observed variation in diameter at breast height for both species. Equations with stump diameter for $30 \mathrm{~cm}$ stump height have better statistical results than for $10 \mathrm{~cm}$ stump height. Power equation (Model 7) had the lowest average rank values $(p<0.05)$ for determining $d_{0.10^{-}} d_{1.30}$ and $d_{0.30^{-}}$ $d_{1.30}$ relationships of both species and provided the best $d_{1.30}$ predictions. $R^{2}, R M S E$ and $M A E$ values of the best model (power equation) are $0.981,3.64$ and 2.58 for $d_{0.10^{-}}$ $d_{1.30}$ relationship and $0.989,2.01$ and 1.36 for $d_{0.30}-d_{1.30}$ relationship for Oriental beech trees, and $0.955,3.80$ and 2.81 for $d_{0.10-} d_{1.30}$ relationship and $0.988,1.96$ and 1.28 for $d_{0.30^{-}}$ $d_{1.30}$ relationship for Kazdağ 1 fir trees, respectively.

The validities of the developed equations were tested with Paired Samples t-Test using independent data sets obtained from 60 and 70 sample trees for beech and fir, respectively. The estimated and observed $d_{1.30}$ values were compared with this test and consequently it was decided that the equations which had statistically non-significant differences between estimated and observed values could be used (Table 4). As seen in the table, there are no significant differences $(p>0.05)$ between observed and estimated values of the most of the equations modeling $d_{0.10}-d_{1.30}$ and $d_{0.30}-d_{1.30}$ relationships for both species. As a result, because of their statistical successes, power equations (Model 7) can be used for 
diameter at breast height estimations based on both stump diameters. In addition, linear equations (Model 1) had also lower average ranks and can be used practically.

Residual plots based on the differences between observed and estimated diameter at breast heights calculated with the power equations for the entire sample trees are given in Figure 2 for Oriental beech and in Figure 3 for Kazdağı fir. When Figure 2 and 3 are examined, it is seen that the residuals increase together with the increase in diameter at breast height and then decrease again for high diameter at breast height values. When the diameter at breast height estimations based on stump diameters at two different stump heights are compared, the residuals of estimations based on stump diameter at $30 \mathrm{~cm}$ are lower for both species. Mean residuals are very close to zero for all estimations.

Table 3. Parameter estimations, goodness of fit statistics and ranks based on fit statistics of models*

\begin{tabular}{|c|c|c|c|c|c|c|c|c|c|c|}
\hline $\begin{array}{c}\text { Model } \\
\text { No. }\end{array}$ & $b_{0}$ & $b_{1}$ & $b_{2}$ & $b_{3}$ & $F$ & $p$ & $R^{2}$ & $R M S E$ & $M A E$ & $\begin{array}{c}\text { Average } \\
\text { Rank }\end{array}$ \\
\hline \multicolumn{11}{|c|}{ Fagus orientalis } \\
\hline 1 & -1.660 & 0.874 & & & 3472.105 & 0.000 & $0.952(3.5)$ & $3.61(2)$ & $2.62(2.5)$ & 2.67 \\
\hline 2 & -113.603 & 40.535 & & & 1631.426 & 0.000 & $0.903(6)$ & $5.13(6)$ & $3.93(5)$ & 5.67 \\
\hline 3 & 75.869 & -1437.746 & & & 525.876 & 0.000 & $0.749(10)$ & $8.24(10)$ & $6.40(10)$ & 10.00 \\
\hline 6 & 13.205 & 1.022 & & & 1449.409 & 0.000 & $0.892(8)$ & $2.16(1)$ & $4.38(7)$ & 5.33 \\
\hline 7 & 0.647 & 1.068 & & & 4571.443 & 0.000 & $0.981(1)$ & $3.64(4)$ & $2.58(1)$ & 2.00 \\
\hline 8 & 4.608 & -40.678 & & & 2168.601 & 0.000 & $0.925(5)$ & $5.70(7)$ & $4.12(6)$ & 6.00 \\
\hline 9 & 2.581 & 0.022 & & & 1449.409 & 0.000 & $0.892(8)$ & $6.69(9)$ & $4.46(8.5)$ & 8.50 \\
\hline 10 & 13.205 & 0.022 & & & 1449.409 & 0.000 & $0.892(8)$ & $6.68(8)$ & $4.46(8.5)$ & 8.17 \\
\hline \multicolumn{11}{|c|}{ Diameter at breast height - Stump diameter at $30 \mathrm{~cm}$} \\
\hline 5 & -5.007 & 1.245 & -0.006 & 0.00003 & 4133.596 & 0.000 & $0.986(3)$ & $2.66(5)$ & $2.04(4)$ & 4.00 \\
\hline 6 & 13.562 & 1.024 & & & 1790.393 & 0.000 & $0.910(8)$ & $2.10(4)$ & $3.97(7)$ & 6.33 \\
\hline 7 & 0.791 & 1.045 & & & 15356.347 & 0.000 & $0.989(1)$ & $2.01(3)$ & $1.36(2)$ & 2.00 \\
\hline 8 & 4.564 & -34.240 & & & 2365.309 & 0.000 & $0.931(5)$ & $5.34(7)$ & $3.71(6)$ & 6.00 \\
\hline 9 & 2.607 & 0.024 & & & 1790.393 & 0.000 & $0.910(8)$ & $6.61(8.5)$ & $4.02(8.5)$ & 8.33 \\
\hline 10 & 13.562 & 0.024 & & & 1790.393 & 0.000 & $0.910(8)$ & $6.61(8.5)$ & $4.02(8.5)$ & 8.33 \\
\hline \multicolumn{11}{|c|}{ Abies nordmanniana subsp. equi-trojani } \\
\hline \multicolumn{11}{|c|}{ Diameter at breast height - Stump diameter at $10 \mathrm{~cm}$} \\
\hline 1 & -3.032 & 0.873 & & & 4079.401 & 0.000 & $0.952(4)$ & $3.82(2)$ & $2.77(2)$ & 2.67 \\
\hline 2 & -120.020 & 41.889 & & & 1588.995 & 0.000 & $0.885(9)$ & $5.91(5)$ & $4.36(8)$ & 7.33 \\
\hline 3 & 77.951 & -1566.848 & & & 560.389 & 0.000 & $0.731(10)$ & $9.05(10)$ & $6.74(10)$ & 10.00 \\
\hline \multicolumn{11}{|c|}{ Diameter at breast height - Stump diameter at $30 \mathrm{~cm}$} \\
\hline 1 & -1.197 & 0.963 & & & 16017.242 & 0.000 & $0.987(3)$ & $1.97(3)$ & $1.29(3)$ & 3.00 \\
\hline 2 & -110.528 & 40.984 & & & 2554.118 & 0.000 & $0.925(9)$ & $4.77(5)$ & $3.51(5)$ & 6.33 \\
\hline 3 & 77.243 & -1317.848 & & & 639.609 & 0.000 & $0.756(10)$ & $8.62(10)$ & $6.39(10)$ & 10.00 \\
\hline 4 & -0.101 & 0.914 & 0.0005 & & 8050.939 & 0.000 & $0.987(3)$ & $1.96(1.5)$ & $1.28(1.5)$ & 2.00 \\
\hline 5 & -1.316 & 0.999 & -0.001 & 0.00001 & 5356.985 & 0.000 & $0.987(3)$ & $2.08(4)$ & $1.31(4)$ & 3.67 \\
\hline 6 & 13.934 & 1.023 & & & 2570.478 & 0.000 & $0.926(7)$ & $6.12(7)$ & $3.82(6)$ & 6.67 \\
\hline 7 & 0.827 & 1.032 & & & 16316.699 & 0.000 & 0.988 (1) & $1.96(1.5)$ & $1.28(1.5)$ & 1.33 \\
\hline 8 & 4.597 & -35.565 & & & 2637.493 & 0.000 & $0.928(5)$ & $5.78(6)$ & $3.83(7)$ & 6.00 \\
\hline 9 & 2.634 & 0.023 & & & 2570.428 & 0.000 & $0.926(7)$ & $6.58(8.5)$ & $3.85(8.5)$ & 8.00 \\
\hline 10 & 13.934 & 0.023 & & & 2570.428 & 0.000 & $0.926(7)$ & $6.58(8.5)$ & $3.85(8.5)$ & 8.00 \\
\hline
\end{tabular}


Table 4. The t-test results for the equations tested

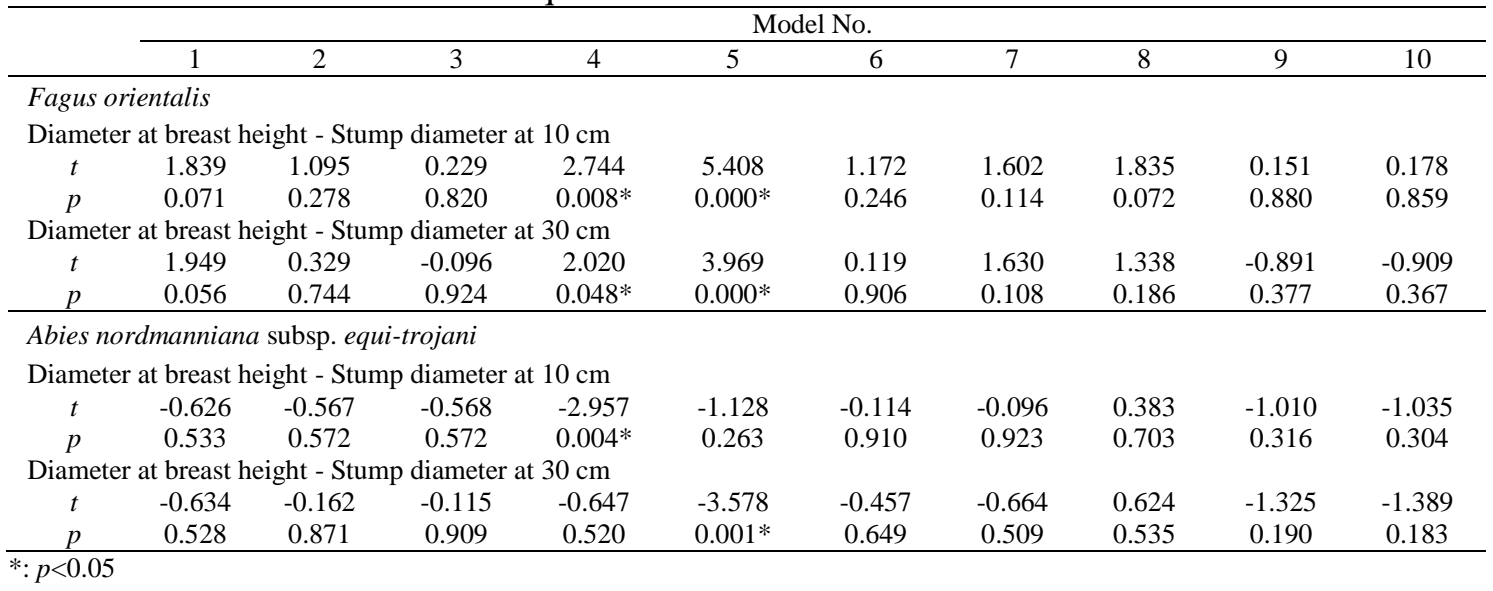
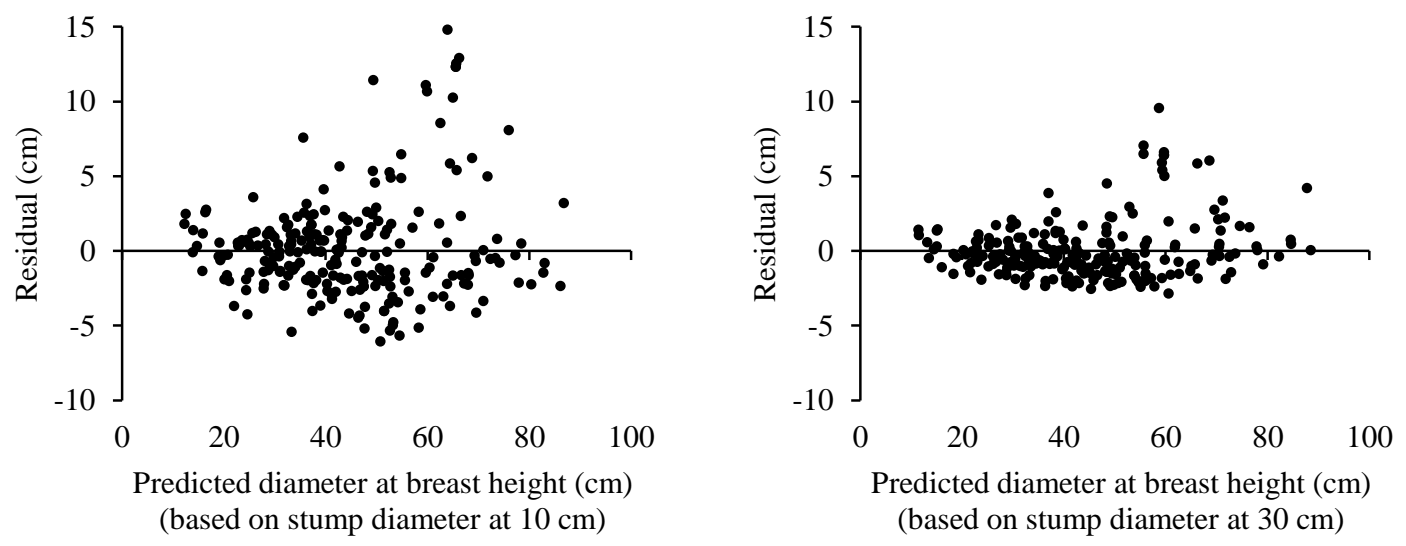

Figure 2. Residuals of diameter at breast height estimations for Fagus orientalis
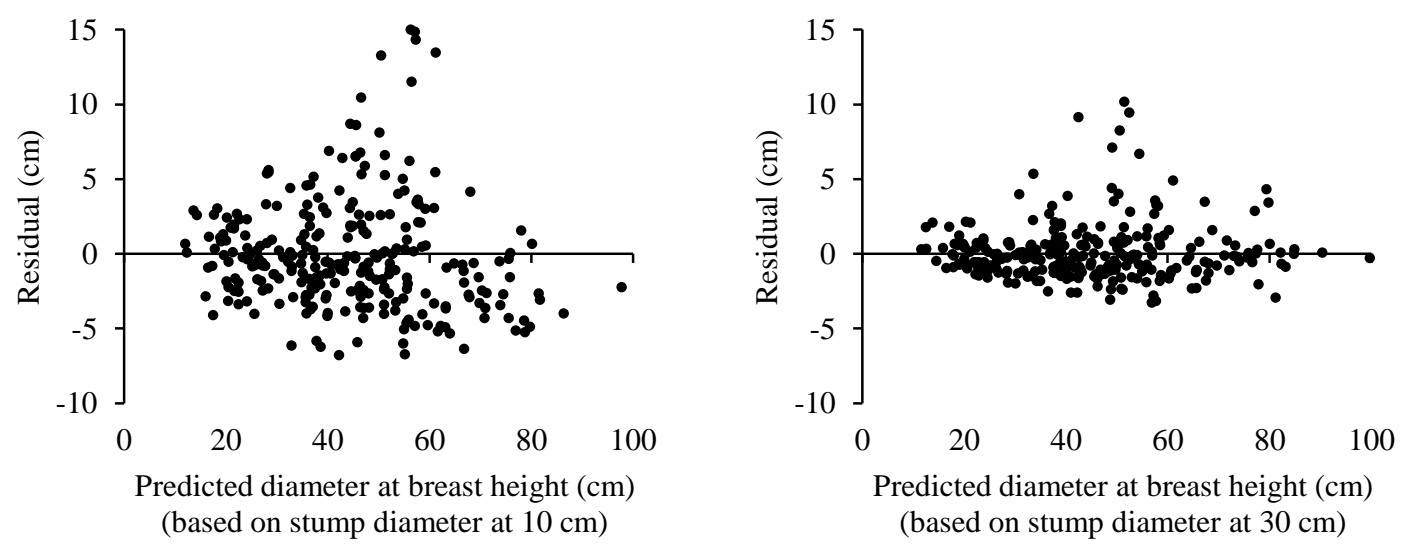

Figure 3. Residuals of diameter at breast height estimations for Abies nordmanniana subsp. equi-trojani

Figure 4 shows the differences for diameter at breast height estimations between tree species studied. When stump diameter at $10 \mathrm{~cm}$ height is used as predictor variable, there are increasing differences in favor of beech in diameter at breast height estimations. If stump diameter at $30 \mathrm{~cm}$ is used as it, the differences are quite small.

For some tree species in Turkey, similar results were also obtained for Scots pine and 
Crimean pine (Yavuz, 1996), Ash (Yavuz, 2000), Cedar and Calabrian pine (Özçelik, 2005), Oriental beech (Ercanlı et al., 2015) and Chestnut (Sağlam et al., 2016) for using the power equations. Besides, quadratic equation was found successful for Crimean pine (Özçelik, 2005) and Scots pine (Şenyurt, 2012).

Results found in this study are also similar to the results of Durkaya and Durkaya (2011), in which relationships between diameter at

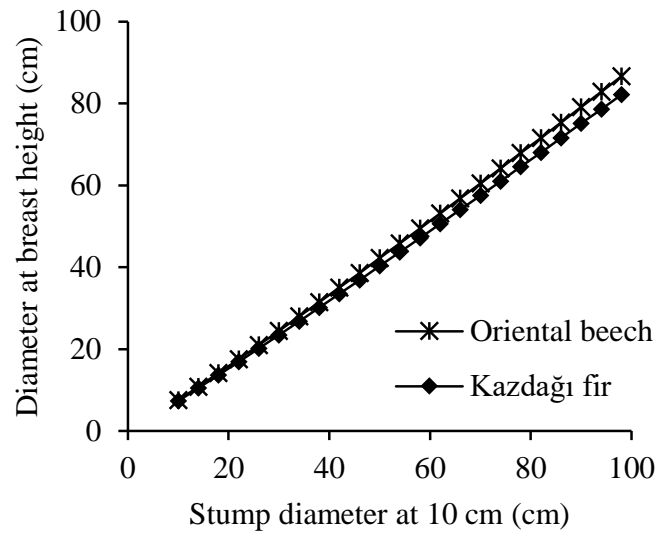

breast height and stump diameters at six different stump heights were studied for mixed stands of three species (fir, beech and black pine) at an area close to our study area. In their research, power equation was also the most successful model to develop stump diameters and diameter at breast height relationships and statistical successes of the models increased with increasing stump heights, especially for beech and fir trees, like present study.

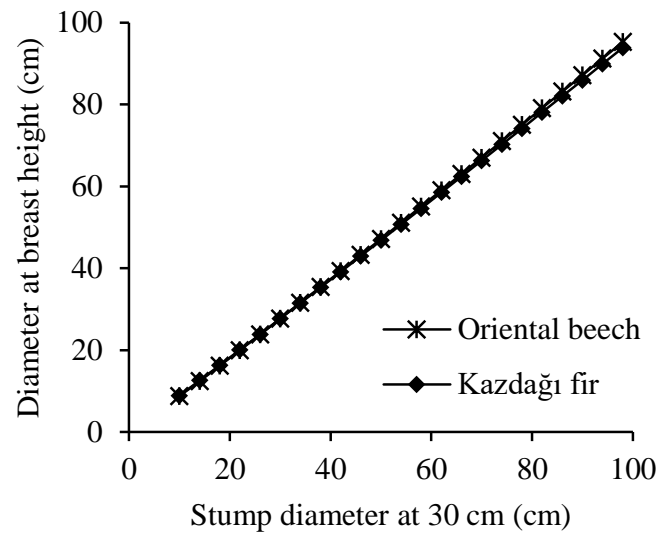

Figure 4. Diameter at breast height estimations for different stump diameters

\section{Conclusions}

In order to determine the relationships of two different stump diameters with diameter at breast height for mixed stands of Oriental beech and Kazdağ regression equations were tested and power equation was selected according to statistical criteria for both relationships. Equations developed for diameter at breast height estimations from stump diameters at $10 \mathrm{~cm}$ and $30 \mathrm{~cm}$ are expressed as follows.

Fagus orientalis:

$$
\begin{aligned}
& d_{1.30}=0.647\left(d_{0.10}\right)^{1.068} \\
& d_{1.30}=0.791\left(d_{0.30}\right)^{1.045}
\end{aligned}
$$

Abies nordmanniana subsp. equi-trojani:

$$
\begin{aligned}
& d_{1.30}=0.637\left(d_{0.10}\right)^{1.060} \\
& d_{1.30}=0.827\left(d_{0.30}\right)^{1.032}
\end{aligned}
$$

These equations can be used to estimate diameters at breast height of trees extracted from the stand for any reason. In this way, volume of these trees may be predicted in a practical way by using single entry volume equations with the estimated diameters at breast heights.
Because of their successful results, linear models can also be used for practicality. Equation forms of linear models are as follows.

Fagus orientalis:

$$
\begin{aligned}
& d_{1.30}=-1.660+0.874 d_{0.10} \\
& d_{1.30}=-0.898+0.961 d_{0.30}
\end{aligned}
$$

Abies nordmanniana subsp. equi-trojani:

$$
\begin{aligned}
& d_{1.30}=-3.032+0.873 d_{0.10} \\
& d_{1.30}=-1.197+0.963 d_{0.30}
\end{aligned}
$$

As other stand characteristics, stump diameter and diameter at breast height relationships vary according to tree species and site conditions. Therefore, it should be established these relationships for different tree species, sites and regions in order to reflect on the results of aforesaid differences and to obtain reliable results.

\section{Acknowledgements}

We would like to thank Büyükdüz Forest Planning Unit staff for their valuable help in field works. We also wish to thank three anonymous reviewers for contributing comments. 


\section{References}

Alemdag, İ.Ş., Honer, T.G. (1977). Metric relationships between breast-height and stump diameter for eleven tree species form Eastern and Central Canada. Canadian Forest Service, Forest Management Institute, Information Report, FMR-X.

Anşin, R., Özkan, Z.C. (1993). Tohumlu Bitkiler (Spermatophyta) Odunsu Taksonlar. KTÜ Basımevi, Genel Yayın No: 167, Fakülte Yayın No: 19, 512 s, Trabzon. (in Turkish)

Bylin, C.V. (1982). Estimating dbh from stump diameter for 15 southern species. Res. Note 50-286. New Orleans, LA: U.S. Department of Agriculture, Forest Service, Southern Forest Experiment Station:3

Corral-Rivas, J.J., Barrio-Anta, M., AgirreCalderón, A.A., Diéguez-Aranda, U. (2007). Use of stump diameter to estimate diameter at breast height and tree volume for major pine species in El Salto Durango (Mexico). Forestry 80, 29-40.

Demaerschalk, J.P., Omule, S.A.Y. (1982). Estimating breast height diameter form stump measurements in British Columbia. The Forestry Chronicle, 58 (3), 143-145.

Durkaya, B., Durkaya, A. (2011). ZonguldakUlus Orman İsletme Müdürlüğü göknar, kayın ve karaçam ağaç türleri için kütük çap1 ve boyu ile gögüs çapı ilişkisi. Kastamonu Üniversitesi Orman Fakültesi Dergisi, 11 (1), 9-17. (in Turkish)

Ercanlı, İ., Günlü, A., Başkent, E.Z. (2015). Mixed effect models for predicting breast height diameter from stump diameter of Oriental beech in Göldağ. Scientia Agricola, 72 (3), 245-251.

Firat, F. (1973). Dendrometri. İstanbul Üniversitesi Yayın No: 1800, Orman Fakültesi Yayın No: 193, 359 s, Kutulmuş Matbaas1, İstanbul. (in Turkish)

Giray, N. (1982). Ağaçlarda kütük çapı, orta çap, gögüs çap1 ilişkisi. Ormancıllk Araştırma Enstitüsü Dergisi, 28, 69-79. (in Turkish)

Kalıpsız, A. (1999). Dendrometri. İstanbul Üniversitesi, Orman Fakültesi Yayını, No:3194/354, İstanbul. (in Turkish)

Köhl, M. (2004). Forest Inventory and Monitoring, (Editors: Burley, J., Evans, J.,
Youngquist, J.A., Encyclopedia of Forest Science), 403-409, Elsevier, Spain,.

Kozak, A., Omule, S.A.Y. (1992). Estimating stump volume, stump inside bark diameter and diameter at breast height form stump measurements. The Forestry Chronicle, 68 (5), 623-627.

Omule, S.A.Y., Kozak, A. (1989). Stump and breast height diameter tables for British Columbia tree species. FRDA Report 062.

Özçelik, R. (2005). Mut Orman İşletmesinde karaçam, sedir ve kızılçam ağaç türleri için dip çap-gögüs çap1 ilişkileri. SDÜ Fen Bilimleri Enstitüsü Dergisi, 9 (3), 83-91. (in Turkish)

Özer, E. (1981). Sarıçamlarda kütük çapından yararlanarak göğüs çapının bulunması. Ormancılık Araştırma Enstitüsü Dergisi, 27, 20-23. (in Turkish)

Sağlam, F., Sakıcı, O.E., Seki, M. (2016). The relationships between stump diameter and diameter at breast height for Chestnut (Castanea sativa Mill.) stands in Kastamonu coastal region, International Forestry Symposium, (7-10 December 2016), 514-520, Kastamonu, Turkey.

Şenyurt, M. (2012). Batı Karadeniz yöresi sarıçam meşcerelerinde kütük çapı-göğüs çap1 ilişkileri. Artvin Çoruh Üniversitesi Orman Fakültesi Dergisi, 13 (1),79-87. (in Turkish)

Uğurlu, S., Özer, E. (1977). Kızılçamlarda kütük çapından yararlanarak gögüs çapının bulunmas1. Ormancilı Araştırma Enstitüsü Dergisi, 23, 71-77. (in Turkish)

URL, (2017). Karabük Forest Enterprise Asset, http://zonguldakobm.ogm.gov.tr/ KarabukOIM/Lists/OrmanVarligi/AllItem s.aspx (June 15, 2017)

Vanclay, J.K. (1994). Modelling Forest Growth and Yield: Applications to Mixed Tropical Forests. ISBN: 0851989136, 312 $\mathrm{p}, \mathrm{CAB}$ International.

Weigel, D.R., Johnson, P.S. (1997). Estimating dbh of southern Indiana oaks from stump diameter. Tech. Brief TB-NC4 USDA Forest Service North Central Forest Experiment Station.

Yavuz, H. (1996). Taşköprü Orman İşletmesinde sarıçam ve karaçam ağaç türlerimize ilişkin dip çap-göğüs çap1-orta çap ilişkileri ile kabuk hacminin hesaplanmasi. K.T.Ü Orman Fakültesi 
Bahar Yar1 Y1l Seminerleri, Seminer No:2, 67-75. (in Turkish)

Yavuz, H. (2000). Dişbudak ağaç türü için dip kütük çap1 ile gögüs çap1 arasındaki ilişkinin belirlenmesi. K.T.Ü Orman Fakültesi Güz Yarı Yı1ı Seminerleri, Seminer No:7, 10s. (in Turkish) 